\title{
Effect of hydrostatic high-pressure processing on the chemical, functional, and rheological properties of starter-free Queso Fresco ${ }^{1}$
}

\author{
D. L. Van Hekken, ${ }^{* 2}$ M. H. Tunick, ${ }^{*}$ N. Y. Farkye, $†$ and P. M. Tomasula* \\ *Dairy and Functional Foods Research Unit, Eastern Regional Research Center, Agricultural Research Service, \\ United States Department of Agriculture, Wyndmoor, PA 19038 \\ †Dairy Products Technology Center, California Polytechnic State University, San Luis Obispo 93407
}

\section{ABSTRACT}

Queso Fresco (QF), a popular high-moisture, high$\mathrm{pH}$ Hispanic-style cheese sold in the United States, underwent high-pressure processing (HPP), which has the potential to improve the safety of cheese, to determine the effects of this process on quality traits of the cheese. Starter-free, rennet-set QF (manufactured from pasteurized, homogenized milk, milled before hooping, and not pressed) was cut into $4.5-\times 4.5-\times 15-\mathrm{cm}$ blocks and double vacuum packaged. Phase 1 of the research examined the effects of hydrostatic HPP on the quality traits of fresh QF that had been warmed to a core temperature of 20 or $40^{\circ} \mathrm{C}$; processed at 200,400 , or 600 $\mathrm{MPa}$ for 5,10 , or $20 \mathrm{~min}$; and stored at $4^{\circ} \mathrm{C}$ for 6 to $8 \mathrm{~d}$. Phase 2 examined the long-term effects of HPP on quality traits when QF was treated at $600 \mathrm{MPa}$ for 3 or 10 min, and stored at 4 or $10^{\circ} \mathrm{C}$ for up to $12 \mathrm{wk}$. Warming the $\mathrm{QF}$ to $40^{\circ} \mathrm{C}$ before packaging and exposure to high pressure resulted in loss of free whey from the cheese into the package, lower moisture content, and harder cheese. In phase 2 , the control QF, regardless of aging temperature, was significantly softer than HPP cheeses over the 12 wk of storage. Hardness, fracture stress, and fracture rigidity increased with length of exposure time and storage temperature, with minor changes in the other properties. Queso Fresco remained a bright white, weak-bodied cheese that crumbled and did not melt upon heating. Although high pressures or long processing times may be required for the elimination of pathogens, cheese producers must be aware that HPP altered the rheological properties of $\mathrm{QF}$ and caused wheying-off in cheeses not pressed before packaging.

Key words: cheese, Queso Fresco, high-pressure processing, texture

Received September 28, 2012.

Accepted July 5, 2013.

${ }^{1}$ Mention of trade names or commercial products in this publication is solely for providing specific information and does not imply recommendation or endorsement by the US Department of Agriculture.

${ }^{2}$ Corresponding author: diane.vanhekken@ars.usda.gov

\section{INTRODUCTION}

Hispanic-style cheeses now comprise $2 \%$ of all cheeses manufactured in the United States (USDA-NASS, 2013) because of the increase in the Hispanic population and the popularity of Latin cuisine. Queso Fresco $(\mathbf{Q F})$ is one of the most popular fresh Hispanic-style cheeses made and consumed in the Americas. It is a bright white, high-moisture cheese that typically does not melt and has a mild, fresh-milk flavor with a distinct salty note. The cheese can contain 46 to $57 \%$ moisture, 18 to $29 \%$ fat, 17 to $21 \%$ protein, and 1 to $3 \%$ salt; in the United States, QF has a $\mathrm{pH} \geq 6.1$ (Van Hekken and Farkye, 2003).

Queso Fresco in the United States is made from pasteurized milk, thereby significantly reducing the microbial load in the cheesemilk; however, postpasteurization contamination and growth of pathogens and spoilage bacteria can be a problem in many unripened soft cheeses (MacDonald et al., 2005). High hydrostatic pressure processing, commonly referred to as high-pressure processing (HPP), of cheese is being considered as a postpackaging treatment because of its lethality to bacteria and potential to extend shelf life (Trujillo et al., 2002; Evrendilek et al., 2008; Chawla et al., 2011). Studies involving starter-free, high-moisture Mató goat cheese reported that HPP was more effective in reducing bacterial loads if cheeses were processed at $50^{\circ} \mathrm{C}$ compared with 4 or $25^{\circ} \mathrm{C}$ (Capellas et al., 2000) and that processing at $500 \mathrm{MPa}$ and 10 or $25^{\circ} \mathrm{C}$ did not alter the composition and had minor effect on whey retention, texture, microstructure, or color of the cheese (Capellas et al., 2001). A study in which fresh bovine lactic acid cheese curd was processed at pressures ranging from 300 to $600 \mathrm{MPa}$ found no significant differences in sensorial or textural properties among controls and HPP samples (Daryaei et al., 2006). Another study in which fresh, starter-free bovine cheese was processed at 300 to $400 \mathrm{MPa}$ reported that HPP resulted in firmer cheese with more yellow color (Evert-Arriagada et al., 2012). A study of $\mathrm{QF}$ processed at $400 \mathrm{MPa}$ also found HPP cheeses to be more yellow in color and slightly less 
crumbly but overall very similar to the non-HPP control QF (Sandra et al., 2004). In a study of QF prepared with starter culture, pressed, and processed at 400 and $600 \mathrm{MPa}$ for 1 to $25 \mathrm{~min}$. Hnosko et al. (2012) reported that HPP was detrimental to the crumbly quality of $\mathrm{QF}$, a signature quality trait of the cheese. Although pressures at and above $400 \mathrm{MPa}$ are required to significantly reduce microbial counts in QF (Capellas et al., 2000; Hnosko et al., 2012), there are conflicting results as to the effect of HPP on the texture of QF (Sandra et al., 2004; Hnosko et al., 2012). More information is required on the effects that these high pressures have on the physical quality traits of the cheese before HPP can be incorporated into commercial cheese production.

This study examined the effect of hydrostatic HPP on the quality traits (chemical, functional, and rheological properties) of QF made without starter cultures or pressing, first by measuring short-term effects using several combinations of HPP operating conditions and second by measuring long-term effects using HPP at $600 \mathrm{MPa}$ for either 3 or $10 \mathrm{~min}$ followed by storage at 4 or $10^{\circ} \mathrm{C}$ for up to $12 \mathrm{wk}$.

\section{MATERIALS AND METHODS}

\section{Manufacture and Processing of QF}

Raw milk obtained from a local dairy was used to manufacture QF, as described by Leggett et al. (2012) based on a commercial protocol that specifically does not use starter cultures or press the large blocks of QF before vacuum packaging (Figure 1). Salt was added at a level of $14.5 \mathrm{~g}$ of $\mathrm{NaCl}$ per $\mathrm{L}$ of milk. Cheeses were stored overnight at $4^{\circ} \mathrm{C}$ before being removed from the mold on d 2. All cheese, except portions for sensory evaluation, were cut into rectangular blocks approximately $4.5 \times 4.5 \times 15 \mathrm{~cm}$, double vacuum packaged (to ensure containment) in $20 \mathrm{~cm} \times 25 \mathrm{~cm}$ nylon/ polyethylene Prime Source pouches (Koch Equipment Co., Kansas City, MO) using a vacuum packager (Koch Equipment Co.), and stored overnight at $4^{\circ} \mathrm{C}$. On d 3 , samples to receive HPP treatment were processed one at a time in a 2L-700 Laboratory Food Processing System (Avure Technologies, Columbus, $\mathrm{OH}$ ) and then stored at $4^{\circ} \mathrm{C}$ until assayed (see the next section for more details on the HPP unit).

For phase 1, 4 batches of cheese were manufactured over a 4 -wk period. On d 3 after manufacture, samples were removed from the refrigerator and warmed to a core temperature of $20^{\circ} \mathrm{C}$ (first and second batches) or $40^{\circ} \mathrm{C}$ (third and fourth batches) in a water bath. Processing treatments were conducted at 200,400 , or $600 \mathrm{MPa}$ for a total of 5,10 , or $20 \mathrm{~min}$, with 3 blocks per treatment. Controls were warmed to $20^{\circ} \mathrm{C}$ (all 4 batches) or $40^{\circ} \mathrm{C}$ (third and fourth batches) but not exposed to HPP. Thirty cheese blocks were prepared for each of the first and second batches and 33 blocks for each of the third and fourth batches. Samples were stored at $4^{\circ} \mathrm{C}$ until assayed, approximately 6 to $8 \mathrm{~d}$ after manufacture.

For phase 2, 3 batches of QF were manufactured over a 2-mo period. On d 3 after manufacture, the bagged samples were removed from the refrigerator, warmed to $20^{\circ} \mathrm{C}$, and divided into 3 groups. The control samples were not exposed to HPP, whereas the other 2 groups were processed at $600 \mathrm{MPa}$ for either 3 or $10 \mathrm{~min}$. Based on results from phase 1, processing the $\mathrm{QF}$ at $20^{\circ} \mathrm{C}$ resulted in the least amount of wheying-off before the actual HPP, and $600 \mathrm{MPa}$ was selected because, in a concurrent study, it was the most effective pressure used in phase 1 that immediately inactivated Listeria monocytogenes. Half of the cheese from each treatment was placed in storage at 4 or $10^{\circ} \mathrm{C}$. Two blocks of cheese from each treatment were removed and divided for various assays after $1,4,8$, or 12 wk of aging.

Cheese $(16 \mathrm{~kg})$ for sensory evaluation was taken from the second batch of cheese in phase 2 , cut into 6 blocks of $10 \times 14 \times 16 \mathrm{~cm}$, and double bagged in 30.5- $\times 40.6-$ $\mathrm{cm}$ pouches (Koch Equipment Co.). Two blocks were stored at $4^{\circ} \mathrm{C}$ for nontreated controls and the remaining 4 blocks were packaged on ice for overnight shipment to a commercial high-pressure processing laboratory. On the day of arrival, samples were warmed to room temperature for $1 \mathrm{~h}$ and processed 2 samples at a time at $600 \mathrm{MPa}$ for either 3 or $10 \mathrm{~min}$ using a $35 \mathrm{~L}-600$ HPP System (Avure) with a 48-cm-high chamber (19 $\mathrm{cm}$ i.d.). Cheese blocks were repackaged on fresh ice and returned by overnight shipment. Upon arrival, all bags of QF for sensory testing (control and HPP) were aseptically opened, and samples obtained from the interior of the block were sent to a licensed laboratory to confirm the microbial safety of the cheese before presentation to panelists. Each block of cheese was vacuum sealed into a fresh sterile bag, and stored at $4^{\circ} \mathrm{C}$ until the day of sensory testing.

\section{High-Pressure Food Processor}

The Avure 2L-700 unit has a system pressure limit of $690 \mathrm{MPa}$ and a temperature operating range of 10 to $90^{\circ} \mathrm{C}$. The pressure vessel has an inner vessel diameter of $10.0 \mathrm{~cm}$ and a height of $25.4 \mathrm{~cm}$ and holds a basket with dimensions of $7.6 \times 24.1 \mathrm{~cm}$. The times to reach the target pressures of 200,400 , and $600 \mathrm{MPa}$ were 1.3 , 1.9, and $2.5 \mathrm{~min}$, respectively. The Avure $35 \mathrm{~L}$ unit has a pressure limit of $600 \mathrm{MPa}$ and a temperature operating range of 4 to $50^{\circ} \mathrm{C}$. It consists of a Quintus pressure vessel with an inner vessel diameter of $19 \mathrm{~cm}$ and height 


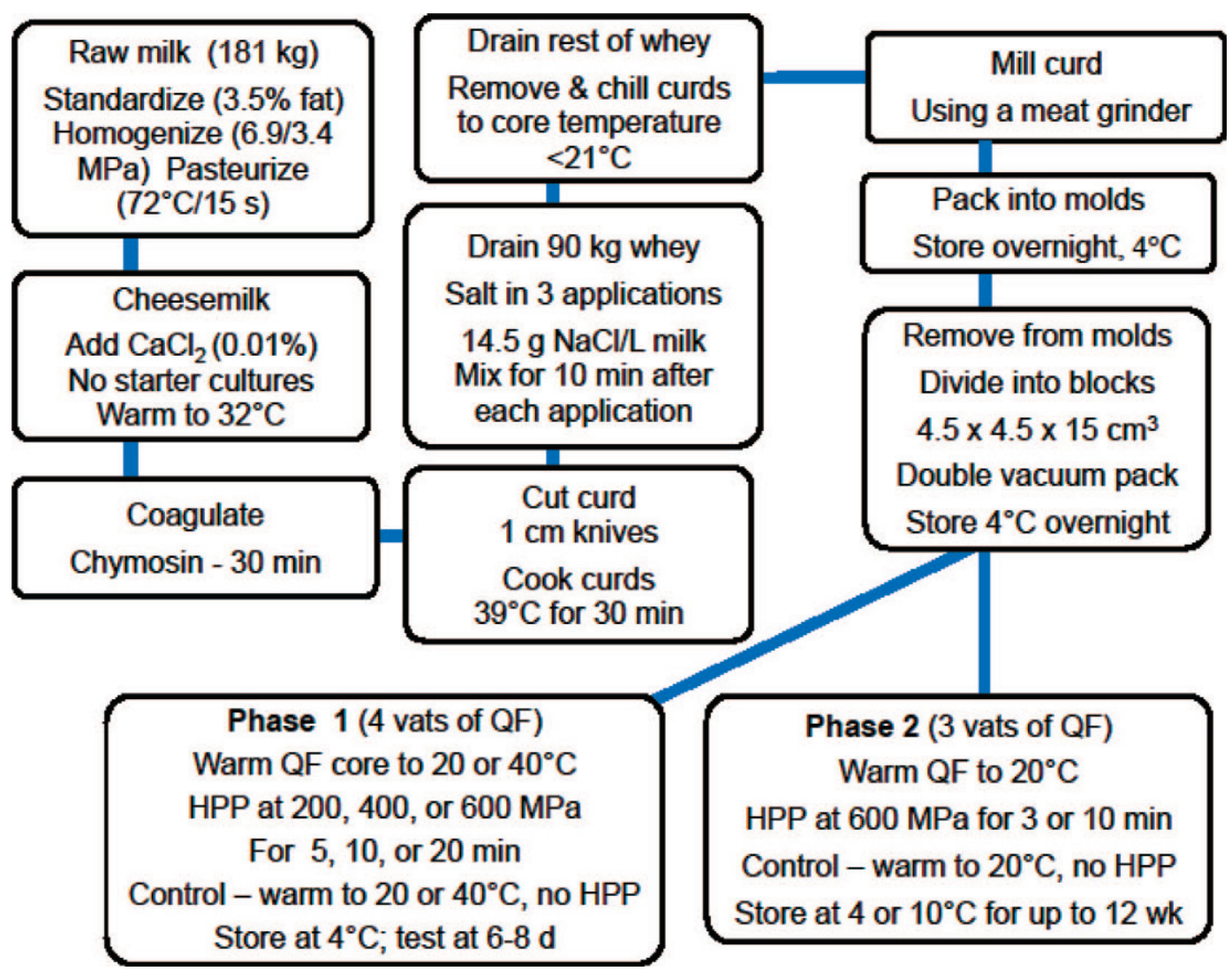

Figure 1. Flowchart of manufacture of Queso Fresco (QF) and processing at high temperatures. HPP = high-pressure processing. Color version available in the online PDF.

of $122 \mathrm{~cm}$ and holds a basket with dimensions of $17.1 \times$ $114 \mathrm{~cm}$. Time to come up to $600 \mathrm{MPa}$ was $2 \mathrm{~min}$. Both units depressurize in less than $0.5 \mathrm{~s}$, use filtered distilled water as the pressure medium, surround the chamber with a water jacket to regulate vessel temperature, and have a thermocouple within the pressurizing chamber to record processing temperatures. The action of the HPP unit is regulated by a control system that contains a recipe editor to define the set points of the system operation. System operation included steps for heating the pressurizing fluid to the set-point temperature, pressurizing the vessel to the set-point pressure, setting the soak or holding time for the chosen temperature and pressure, and depressurizing the vessel to atmospheric pressure. The real-time responses of pressure versus holding time and temperature versus holding time were displayed on a computer monitor.

\section{Composition and $\mathrm{pH}$}

Composition and $\mathrm{pH}$ were measured as described by Guo et al. (2011). The forced-draft oven method (method 948.12; AOAC International, 2000) was used to determine moisture levels in triplicate. Fat percentages were determined in duplicate by the modified Babcock procedure (Kosikowski and Mistry, 1997). A Flash EA1112 nitrogen analyzer (Thermo Fisher Scientific, Lakewood, NJ) was used to measure nitrogen content, in duplicate, which was then multiplied by 6.38 to obtain protein levels. A lactose analyzer (Application Note \#320, model YSI 2700 Select; YSI US, Yellow Springs, OH) was used to measure lactose concentrations in triplicate warm water filtrates. Ash levels were determined in triplicate with an ash furnace (Lindberg Furnace, Watertown, WI; method \#945.46; AOAC International, 2000). The $\mathrm{pH}$ was measured at 6 points using a model $611 \mathrm{pH}$ meter with a pointed probe (Orion Research Corp., Cambridge, MA).

\section{Functional Properties}

Queso Fresco is often used in cooked dishes; therefore, the amount of browning (color change) of the cheese when heated is an important functional property to the consumer. Data on color changes upon heating were obtained with a ColorQuest XE 2382 (Hunter 
Associates Laboratory, Reston, VA) as described by Olson et al. (2007). Six disks $5 \mathrm{~mm}$ (height) $\times 38 \mathrm{~mm}$ (diameter) were cut from each block of cheese (controls and each HPP treatment) and 6 values for $\mathrm{L}^{*}(0$ to 100, black to white), a* (negative, green; positive, red), and $b^{*}$ (positive, yellow; negative, blue) were obtained for each disk before and after heating: 3 were heated at $232^{\circ} \mathrm{C}$ for $5 \mathrm{~min}$ (to mimic broiling conditions) and the remaining 3 were heated at $130^{\circ} \mathrm{C}$ for $30 \mathrm{~min}$ (to mimic baking conditions). All QF heated at $130^{\circ} \mathrm{C}$ had extensive browning around the edge of the disks, which was avoided when collecting color measurements. The change in the $\mathrm{L}^{*}, \mathrm{a}^{*}$, and $\mathrm{b}^{*}$ values collected on the disk before and after heating was used to calculate the total color difference $(\boldsymbol{\Delta} \mathbf{E})$ using equation [1] (Hunter, 1975):

$$
\Delta \mathrm{E}=\left(\Delta \mathrm{L}^{*^{2}}+\Delta \mathrm{a}^{*^{2}}+\Delta \mathrm{b}^{*^{2}}\right)^{1 / 2} .
$$

\section{Textural Properties}

All samples were brought to room temperature $\left(22^{\circ} \mathrm{C}\right)$ before conducting texture tests as described by Guo et al. (2011). A Universal Testing Machine (model SM-25-155, Material Testing Products Systems Corp., Eden Prairie, MN) operating at $100 \mathrm{~mm} / \mathrm{min}$ and programmed for double compressions $(75 \%)$ generated force-time curves for 4 cylinders of cheese (height 14 $\mathrm{mm}$, diameter $14 \mathrm{~mm}$ ) per sample. The curves were used to calculate texture hardness, cohesiveness, chewiness, and springiness.

\section{Rheological Properties}

All samples were brought to room temperature $\left(22^{\circ} \mathrm{C}\right)$ before conducting rheology tests as described by Guo et al. (2011). A Torsion Gelometer (Gel Consultants Inc., Raleigh, NC) operating at $2.5 \mathrm{rpm}$ generated strain-time curves for 4 capstan-shaped cheese plugs per sample. The curves were used to obtain rheology fracture stress, strain, and rigidity. A Dynamic Analyzer (AR-2000, TA Instruments, New Castle, DE) fitted with parallel aluminum plates and operating at $0.8 \%$ strain (within linear viscoelastic range as determined by strain sweeps) and 0.1 to $100 \mathrm{rad} / \mathrm{s}$ generated frequency sweeps for 3 disks ( $25 \mathrm{~mm}$ in diameter, 3 to 4 $\mathrm{mm}$ thick) per cheese sample. Sweep data were used to determine viscoelastic properties (elastic and viscous moduli and complex viscosity, $\eta^{*}$ ).

\section{Microstructure}

Microstructure was evaluated for samples in phase 1 according to the procedure described by Tunick et al.
(2008). Small sample pieces $\left(2 \mathrm{~mm}^{3}\right)$ from each HPP treatment were preserved in $2.5 \%$ glutaraldehyde- 0.1 $M$ imidazole, dehydrated through a series of ethanol rinses, frozen and freeze fractured, dried to critical point, and sputter-coated onto stubs. A scanning electron microscope (Quanta 200 field emission SEM, FEI Co., Hillsboro, OR) was used to view samples and obtain images.

\section{Sensory Evaluations}

Nine days after manufacture, the 6 large blocks of cheese were cut into $2.5-\mathrm{cm}^{3}$ samples, placed in coded, 3 -oz., capped plastic cups, and refrigerated at $4^{\circ} \mathrm{C}$ in preparation for hedonic and difference tests. All cheeses were warmed to room temperature $\left(22^{\circ} \mathrm{C}\right) 30 \mathrm{~min}$ before presentation to untrained in-house panelists $(\mathrm{n}=30)$. Each panelist evaluated 3 samples for hedonic liking (9-point scale) and 3 sets of triangle difference testing. Distilled water and unsalted crackers were available to each panelist to clear the palate between samples.

\section{Statistical Analysis}

Statistical analyses of composition, color, and rheological data were conducted using a split-plot design using HPP treatment conditions (core temperature, processing pressure, and exposure time) as main effects for phase 1, and a mixed model multivariate design with processing time, storage temperature, and length of storage as main effects for phase 2 (version 9.12 for Windows; SAS Institute Inc., Cary, NC). Significant differences $(P<0.05)$ among means were compared using the Bonferroni test in the Proc Mixed program. Principle component analysis was conducted according to SAS. Sensory triangle scores collected in phase 2 were evaluated using the critical number of correct responses in triangle tests (Meilgaard et al., 1999).

\section{RESULTS AND DISCUSSION}

\section{HPP Processing}

The hydrostatic pressure of HPP is distributed uniformly throughout a food regardless of its size or shape; however, as the pressure is increased, the temperatures of the pressurizing fluid (PF) and the food increase due to adiabatic heating resulting from the work of compression (Norton and Sun, 2008). The temperature rise (TR) for the $\mathrm{PF}$ and foods depends on their initial temperature and pressure, density, heat capacity, and thermal expansivity. The TR for foods also depends on composition (Rasanayagam et al., 2003). Table 1 shows the relationship between the applied pressure 
Table 1. Temperature rise (TR) in pressurizing fluid (water) as pressure and holding times were increased with initial temperature at 20 or $40^{\circ} \mathrm{C}$

\begin{tabular}{lcrr}
\hline $\begin{array}{l}\text { Initial } \\
\text { temperature }\left({ }^{\circ} \mathrm{C}\right)\end{array}$ & $\begin{array}{c}\text { Pressure } \\
(\mathrm{MPa})\end{array}$ & $\begin{array}{c}\text { Hold time } \\
(\mathrm{min})\end{array}$ & $\begin{array}{r}\mathrm{TR} \\
\left({ }^{\circ} \mathrm{C}\right)\end{array}$ \\
\hline 20.0 & 200 & 5 & 4.0 \\
& & 10 & 4.4 \\
& 400 & 20 & 3.9 \\
& 5 & 10.2 \\
& 10 & 10.8 \\
& 600 & 20 & 9.0 \\
& 5 & 16.6 \\
& & 10 & 15.6 \\
& 200 & 20 & 14.1 \\
& & 5 & 5.0 \\
& & 10 & 6.0 \\
& 400 & 5 & 5.1 \\
& & 10 & 11.8 \\
& & 20 & 11.6 \\
& & 5 & 12.1 \\
& 600 & 10 & 17.1 \\
& & 20 & 14.1 \\
\hline
\end{tabular}

and TR of the PF for HPP trials conducted at holding times of 5,10 , and 20 min. For the PF with an initial temperature of $20^{\circ} \mathrm{C}$, TR ranged from $4^{\circ} \mathrm{C}$ at $200 \mathrm{MPa}$ to $16^{\circ} \mathrm{C}$ at $600 \mathrm{MPa}$. At $40^{\circ} \mathrm{C}$, TR of the $\mathrm{PF}$ upon pressurization showed a small increase relative to the values at $20^{\circ} \mathrm{C}$ because of differences in the physical properties of the water at the higher temperature.

The TR and temperature profiles were determined only for the QF samples with initial temperatures of 20 or $40^{\circ} \mathrm{C}$ that were treated at $600 \mathrm{MPa}$ and held for 10 min (Figure 2). The TR was $25.4^{\circ} \mathrm{C}$ for the QF sample with an initial temperature of $20^{\circ} \mathrm{C}$ (Figure 2a), increasing the temperature at the center of the sample to $45.4^{\circ} \mathrm{C}$ upon pressurization. This is in excellent agreement with the value reported by Hnosko et al. (2012). Hnosko et al. (2012) attributed the greater TR of the cheese sample compared with the PF to the fat content of the cheese that has a lower specific heat, $\mathrm{Cp}$, than that of the PF. Adiabatic heating, which is inversely proportional to $\mathrm{Cp}$, would thus be higher for cheese. The TR for the QF sample with an initial temperature of $40^{\circ} \mathrm{C}$ was $27.7^{\circ} \mathrm{C}$, increasing the temperature of the sample to $67.7^{\circ} \mathrm{C}$ (Figure $2 \mathrm{~b}$ ).

\section{Phase 1}

Composition and $\boldsymbol{p H}$. In phase 1, control QF $\left(20^{\circ} \mathrm{C}\right)$ contained $56.4 \pm 0.8 \%$ moisture, $15.2 \pm 0.6 \%$ protein, $22.1 \pm 0.5 \%$ fat, $2.3 \pm 0.1 \%$ lactose, $2.4 \pm$ $0.3 \%$ salt, and $3.76 \pm 0.18 \%$ ash, and had a $\mathrm{pH} 6.35 \pm$ 0.09. The overall composition fell at the high end of the range for commercial QF available in the United States (Van Hekken and Farkye, 2003). Queso Fresco cheeses manufactured in our facilities (Guo et al., 2011; Tunick et al., 2012; Van Hekken et al., 2012) consistently have higher $\mathrm{pH}$ and higher moisture levels and lower fat and protein contents than those made with starter cultures and pressed before packaging, which results in cheese with a $\mathrm{pH}$ near 5.2 and moisture levels closer to 45 to 50\% (Sandra et al., 2004; Hnosko et al., 2012).

The compositions of the QF were not significantly altered following HPP treatments, with the only exceptions being a few of the protein and moisture means
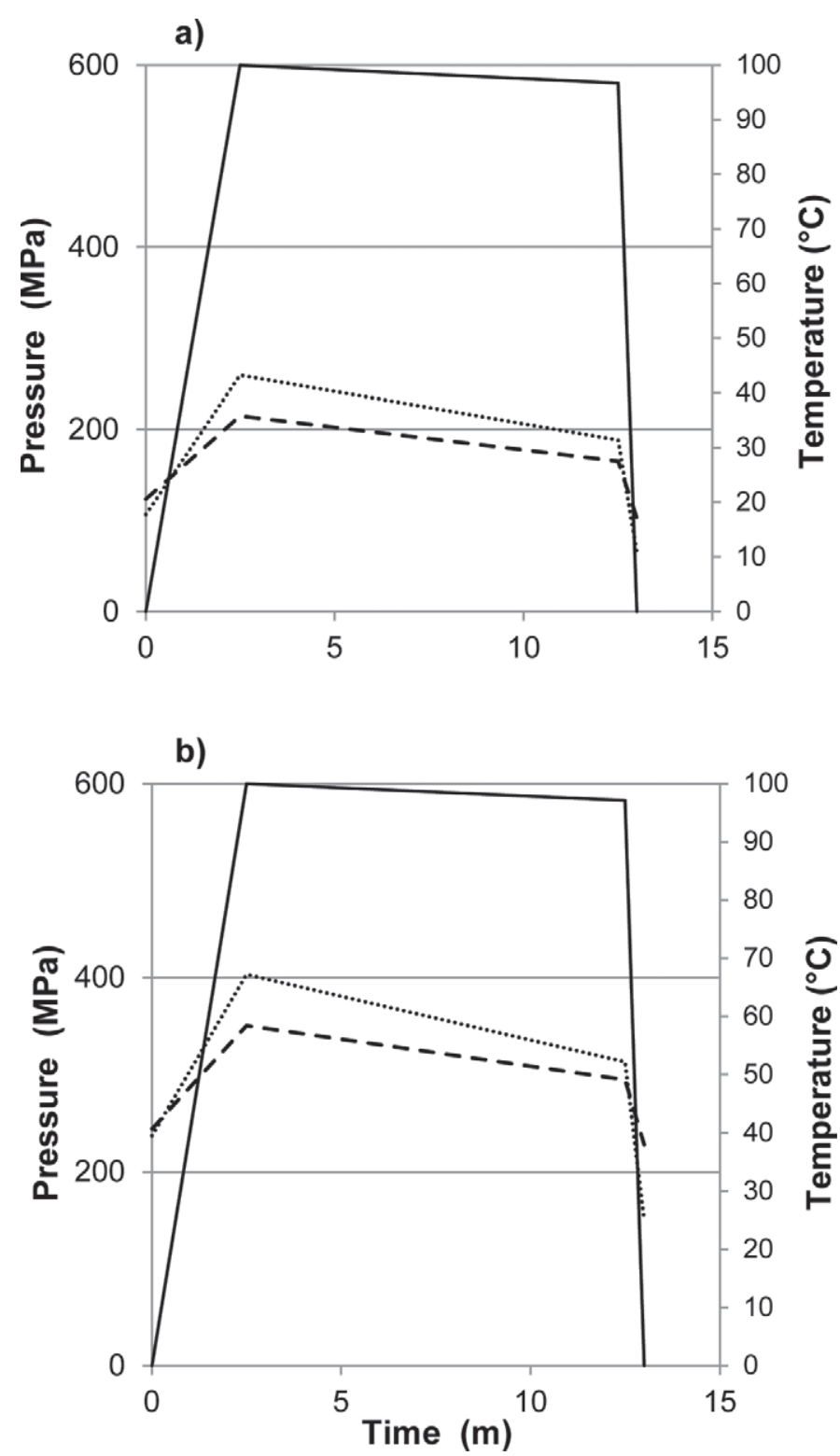

Figure 2. Temperature profiles of pressurizing fluid (dashed line) and Queso Fresco (dotted line) when processed at $600 \mathrm{MPa}$ (solid line indicates pressure) for 10 min with an initial temperature of (a) $20^{\circ} \mathrm{C}$, or (b) $40^{\circ} \mathrm{C}$. 
(Table 2). Protein content of QF ranged from 15.2 to $16.8 \%$, but only that of the $20^{\circ} \mathrm{C}$ control $\mathrm{QF}$ was significantly $(P<0.05)$ lower than that of the $20^{\circ} \mathrm{C}$ QF processed at $400 \mathrm{MPa}$ for $20 \mathrm{~min}$ or $600 \mathrm{MPa}$ for 10 or $20 \mathrm{~min}$. In this study, the slight variations among fat, lactose, and ash levels were not enough to be statistically different $(P>0.05)$. Batch-to-batch variation and differences among the individual treatment cheese blocks would also contribute to the lack of significant difference among the components. Other studies of high-moisture, starter-free cheeses have reported that HPP did not alter the ash, fat, or soluble nitrogen contents in goat cheese (Capellas et al., 2001) or the fat and protein contents in cow cheese (Evert-Arriagada et al., 2012). On the other hand, Okpala et al. (2010) reported significant changes in fat, protein, and moisture contents in fresh, rennet-set, Scottish soft cheeses following HPP from 9 to $291 \mathrm{MPa}$ and for 1 to 29 min. The highest moisture contents were found in the $20^{\circ} \mathrm{C}$ control and the other $\mathrm{QF}$ warmed to $20^{\circ} \mathrm{C}$ and processed at $200 \mathrm{MPa}$ for 5 and $10 \mathrm{~min}$ and were higher $(P<0.05)$ than the QF warmed to $40^{\circ} \mathrm{C}$ and processed at $400 \mathrm{MPa}$ for 5,10 , or $20 \mathrm{~min}$ (Table 2). The moisture levels in the $20^{\circ} \mathrm{C} \mathrm{QF}$ tended to decrease as the pressure and length of treatment increased. The QF warmed to $40^{\circ} \mathrm{C}$ lost $0.8 \%$ free whey before HPP processing and up to another $2 \%$ after processing, with pressure, not exposure time, tending to influence whey loss. The loss of free whey from the cheese matrix into the storage pouch is a combination of the continuation of syneresis and compression of the matrix during HPP treatment and is reflected in the decrease in moisture contents of the QF. Syneresis during the first week of storage of a starter-free, unpressed QF can account for 1.3 to $1.7 \%$ free whey in the package (Van Hekken et al., 2012). In the present study, control QF on d 2 after manufacture had an average of $57.6 \%$ moisture and lost about $1.2 \%$ moisture in the first week of storage, which agrees with our earlier findings. Evert-Arriagada et al. (2012) reported a decrease in moisture of starter-free cow cheese after HPP treatment and contributed it to expulsion of whey from the cheese matrix. By d 7, the amount of whey accumulated in the package was similar among their control and HPP cheeses. Capellas et al. (2001) reported that HPP-treated starter-free goat cheese lost more whey from the matrix than did the control cheese. Other QF HPP studies (Sandra et al., 2004; Hnosko et al., 2012) did not mention wheying-off issues following HPP treatment but both studies incorporated starter cultures and curd pressing before packaging, which facilitate whey drainage from the curd before packaging.

Functionality. All fresh QF were bright white (Figure 3 , Table 3 ), with $L^{*}$ values ranging from 90.2 to 92.9
$(P>0.05)$. The $\mathrm{a}^{*}$ values were positive (red scale) and ranged from 0.080 to 0.517 , with the controls having the highest values and the $\mathrm{QF}$ processed at $600 \mathrm{MPa}$ having lowest values $(P<0.05)$. The $\mathrm{b}^{*}$ values were positive (yellow scale) and ranged from 7.73 to 9.57. Although QF warmed to $20^{\circ} \mathrm{C}$ had similar b* values among the controls and the HPP treatments, the QF warmed to $40^{\circ} \mathrm{C}$ before $\mathrm{HPP}$ at 200 and $400 \mathrm{MPa}$ had higher $\mathrm{b}^{*}$ values $(P<0.05)$. This partly agrees with other reports that cheese was more yellow after HPP (Capellas et al., 2001; Sandra et al., 2004; Okpala et al., 2010; Evert-Arriagada et al., 2012). Johnston and Darcy (2000) suggest that the increased yellowness is because the HPP alters the distribution of the water within the cheese matrix.

Queso Fresco is commonly sliced or shredded and added to dishes that are baked or broiled. Therefore, excessive browning during cooking is an undesirable trait. When QF was heated to $232^{\circ} \mathrm{C}$ for 5 min to mimic broiling conditions (Figure 3, left inset) or to $130^{\circ} \mathrm{C}$ for 30 min to mimic baking conditions (Figure 3, right inset), few of the means for $\mathrm{L}^{*}, \mathrm{a}^{*}$, and $\mathrm{b}^{*}$ and none of the $\Delta \mathrm{E}$ values (Table 3 ) were significantly different among the control and HPP treatments. Queso Fresco heated to $232^{\circ} \mathrm{C}$ for $5 \mathrm{~min}$ had $\Delta \mathrm{E}$ values that ranged from 3.01 to 5.45, with no significant differences among the samples $(P>0.05)$. Only 4 of the $18 \mathrm{~L}^{*}$ means for the HPP treatments were lower $(P<0.05)$ than those of the controls, and 4 of the $20 \mathrm{~b}^{*}$ means, including the control $\mathrm{QF}$ at $20^{\circ} \mathrm{C}$, were lower $(P<0.05)$ than the rest of the samples. Queso Fresco heated to $130^{\circ} \mathrm{C}$ for 30 min had $\Delta \mathrm{E}$ values near the center of the disk that ranged from 12.1 to 22.9 and had excessive browning at the edges. In cheese, browning is primarily a result of the Maillard reaction between the carbonyl groups of lactose, glucose, and galactose and the $\varepsilon$-amino group of protein-bound lysine (Thomas, 1969). As a high-moisture, starter-free cheese, QF in this study contained $2.3 \%$ lactose and 15.2 to $16.8 \%$ protein - ample substrate for the Maillard reaction. The short exposure to $232^{\circ} \mathrm{C}$ resulted in slight puffing of the disk (as steam was generated within the disk) and slight browning at the surface. Prolonged exposure to $130^{\circ} \mathrm{C}$ resulted in drying the edges of the disk to a point of scorching the outer rim. The overall trends noted in the baking or broiling of $\mathrm{QF}$, such as the decrease in $\mathrm{L}^{*}$ values, $\mathrm{a}^{*}$ shifting into the negative green scale, increase $\mathrm{b}^{*}$ yellow values, and the baked samples having a greater total color change than the broiled $\mathrm{QF}$, were in agreement with previously published results (Guo et al., 2011; Tunick et al., 2012).

Textural and Rheological Properties. Highpressure processing had variable effects on the rheol- 


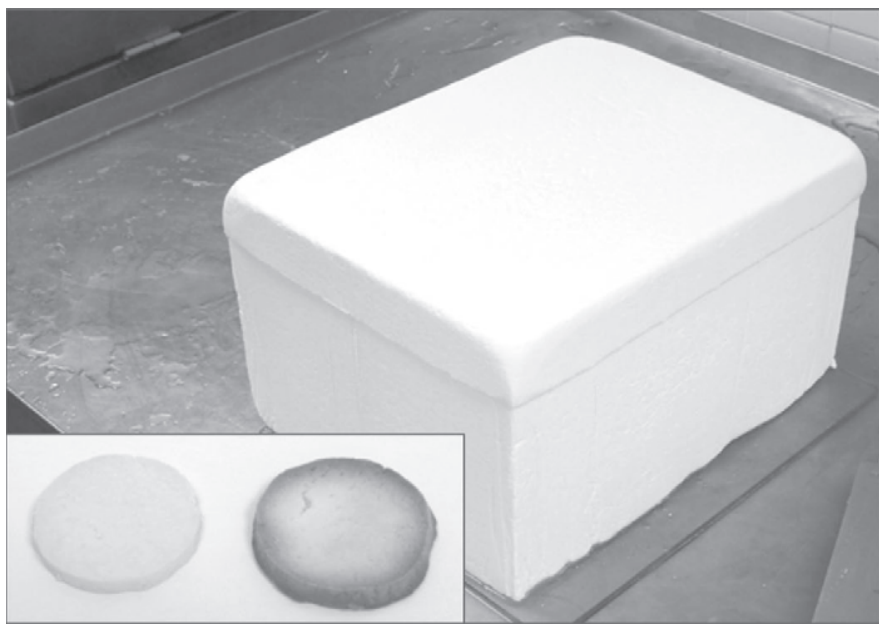

Figure 3. Queso Fresco is a bright white cheese that does not melt upon heating and browns slightly at $232^{\circ} \mathrm{C}$ for 5 min (insert left) and browns around the edges at $130^{\circ} \mathrm{C}$ for $30 \mathrm{~min}$ (insert right).

ogy of the cheese (Figure 4). Four cheeses warmed to $40^{\circ} \mathrm{C}$ and processed at $200 \mathrm{MPa}$ for 5,10 , or $20 \mathrm{~min}$ and at $400 \mathrm{MPa}$ for $5 \mathrm{~min}$ consistently exhibited higher values $(P<0.05)$ for hardness, chewiness, cohesiveness, and springiness (Figure 4a-d) compared with the $\mathrm{QF}$ processed at $20^{\circ} \mathrm{C}$. The fracture stress values were higher $(P<0.05)$ in $\mathrm{QF}$ processed at $40^{\circ} \mathrm{C}$ than at $20^{\circ} \mathrm{C}$ (Figure $4 \mathrm{e}$ ). Queso Fresco cheeses warmed to $40^{\circ} \mathrm{C}$ and processed at 200 or $400 \mathrm{MPa}$ were more flexible than the other treatments as they tolerated more strain (twisting) before fracturing $(P<0.05)$. Four QF warmed to $40^{\circ} \mathrm{C}$ and processed at $400 \mathrm{MPa}$ for $20 \mathrm{~min}$ or at $600 \mathrm{MPa}$ for 5,10 , or $20 \mathrm{~min}$ had the highest fracture rigidity $(P<0.05)$, indicating that cheeses at the highest pressure were more brittle. High-pressure processing of $\mathrm{QF}$ at $20^{\circ} \mathrm{C}$ compressed the protein matrix and forced free whey from the cheese, whereas samples warmed to $40^{\circ} \mathrm{C}$ lost most of their free whey from the cheese before HPP, which then compressed a warmer, more flexible protein matrix. Queso Fresco processed at $40^{\circ} \mathrm{C}$ resulted in firmer cheese with higher values for hardness, chewiness, cohesiveness, fracture stress, and fracture rigidity (Figure 4a, b, c, e, g), whereas those processed at $20^{\circ} \mathrm{C}$ had less variation among treatments and were closest to the non-HPP control. Viscoelastic properties did not vary significantly among cheeses (Figure $4 \mathrm{~h}-\mathrm{j}$ ), an indication that processing did not affect the ability of the casein strands to disentangle during an oscillation.

Principal component (PC) analysis of the texture and rheological data (Figure 5) was conducted to determine relationships among the data, with the first and second $\mathrm{PC}$ accounting for $80.1 \%$ of the variation. The $\mathrm{QF}$ warmed to $20^{\circ} \mathrm{C}$ (enclosed by triangles) and processed 
Table 3. Color data ( $\mathrm{L}^{*}, \mathrm{a}^{*}, \mathrm{~b}^{*}$, and total color difference, $\left.\Delta \mathrm{E}\right)$ of Queso Fresco controls and high-pressure processed (200, 400, or 600 MPa for 5,10 , or $20 \mathrm{~min}$ ) samples before and after heating at $232^{\circ} \mathrm{C}$ for $5 \mathrm{~min}$ or $130^{\circ} \mathrm{C}$ for $30 \mathrm{~min}^{1}$

\begin{tabular}{|c|c|c|c|c|c|c|c|c|c|c|c|}
\hline $\begin{array}{l}\text { Pressure/time } \\
(\mathrm{MPa} / \mathrm{min})\end{array}$ & Before & $232^{\circ} \mathrm{C}$ & $130^{\circ} \mathrm{C}$ & Before & $232^{\circ} \mathrm{C}$ & $130^{\circ} \mathrm{C}$ & Before & $232^{\circ} \mathrm{C}$ & $130^{\circ} \mathrm{C}$ & $232^{\circ} \mathrm{C}$ & $130^{\circ} \mathrm{C}$ \\
\hline \multicolumn{12}{|l|}{ Warmed to $20^{\circ} \mathrm{C}$} \\
\hline $200 / 5$ & $\begin{array}{l}92.5 \\
92.5\end{array}$ & $89.8^{\mathrm{a}}$ & $78.5^{\mathrm{ab}}$ & $0.327^{\mathrm{ab}}$ & $\begin{array}{l}-0.100 \\
-0.115\end{array}$ & $\begin{array}{l}-1.040 \\
-1.240^{\mathrm{a}}\end{array}$ & $\begin{array}{l}0.41 \\
7.73^{\mathrm{c}}\end{array}$ & $\begin{array}{c}10.4 \\
9.30^{\mathrm{b}}\end{array}$ & $16.2^{\mathrm{ab}}$ & $\begin{array}{l}3.30 \\
3.01\end{array}$ & 20.0 \\
\hline $200 / 10$ & 91.8 & $89.2^{\mathrm{a}}$ & $77.3^{\mathrm{ab}}$ & $0.253^{\mathrm{bc}}$ & -0.212 & $-2.013^{\mathrm{ab}}$ & $8.19^{\mathrm{c}}$ & $9.45^{\mathrm{b}}$ & $12.1^{\mathrm{b}}$ & 3.20 & $\begin{array}{l}10.6 \\
15.5\end{array}$ \\
\hline $200 / 20$ & 91.2 & $87.5^{\mathrm{ab}}$ & $76.6^{\mathrm{ab}}$ & $0.297^{\mathrm{abc}}$ & -0.493 & $-1.633^{\mathrm{ab}}$ & $8.50^{\mathrm{bc}}$ & $11.3^{\mathrm{ab}}$ & $15.0^{\mathrm{ab}}$ & 4.65 & 16.2 \\
\hline $400 / 20$ & 91.2 & $87.1^{\mathrm{b}}$ & $77.3^{\mathrm{ab}}$ & $0.190^{\mathrm{bc}}$ & -0.393 & $-1.182^{\mathrm{a}}$ & $8.09^{\mathrm{c}}$ & $11.4^{\mathrm{ab}}$ & $17.0^{\mathrm{ab}}$ & 5.40 & 16.7 \\
\hline $600 / 5$ & 91.0 & $85.4^{\mathrm{b}}$ & $76.6^{\mathrm{ab}}$ & $0.157^{\mathrm{c}}$ & -0.723 & $-1.155^{\mathrm{a}}$ & $8.11^{\mathrm{c}}$ & $12.7^{\mathrm{a}}$ & $17.2^{\mathrm{ab}}$ & 5.45 & 17.3 \\
\hline $600 / 10$ & 91.3 & $87.8^{\mathrm{ab}}$ & $80.5^{\mathrm{a}}$ & $0.110^{\mathrm{c}}$ & -0.431 & $-0.756^{\mathrm{a}}$ & $8.16^{\mathrm{c}}$ & $11.5^{\mathrm{ab}}$ & $18.0^{\mathrm{a}}$ & 5.15 & 16.4 \\
\hline $600 / 20$ & 90.2 & $86.5^{\mathrm{b}}$ & $77.6^{\mathrm{ab}}$ & $0.128^{\mathrm{c}}$ & -0.567 & $-0.813^{\mathrm{a}}$ & $8.26^{\mathrm{bc}}$ & $11.7^{\mathrm{a}}$ & $18.4^{\mathrm{a}}$ & 5.06 & 16.4 \\
\hline \multicolumn{12}{|l|}{ Warmed to $40^{\circ} \mathrm{C}$} \\
\hline $0 / 0$ (control) & 92.9 & $90.2^{\mathrm{a}}$ & $77.6^{\mathrm{ab}}$ & $0.517^{\mathrm{a}}$ & -0.150 & $-2.175^{\mathrm{ab}}$ & $8.69^{\mathrm{bc}}$ & $11.2^{\mathrm{ab}}$ & $14.7^{\mathrm{ab}}$ & 3.91 & 16.5 \\
\hline $200 / 5$ & 91.8 & $88.1^{\mathrm{ab}}$ & $68.7^{\mathrm{b}}$ & $0.347^{\mathrm{ab}}$ & -0.097 & $-2.963^{\mathrm{b}}$ & $9.40^{\mathrm{a}}$ & $12.6^{\mathrm{a}}$ & $12.9^{\mathrm{b}}$ & 4.86 & 22.9 \\
\hline $600 / 5$ & 92.6 & $87.8^{\mathrm{ab}}$ & $80.3^{\mathrm{a}}$ & $0.083^{\mathrm{c}}$ & -0.556 & $-1.245^{\mathrm{a}}$ & $8.99^{\mathrm{ab}}$ & $12.7^{\mathrm{a}}$ & $16.1^{\mathrm{ab}}$ & 5.20 & 14.8 \\
\hline $600 / 10$ & 92.3 & $90.7^{\mathrm{a}}$ & $82.9^{\mathrm{a}}$ & $0.143^{\mathrm{c}}$ & -0.173 & $-0.887^{\mathrm{a}}$ & $8.61^{\text {bc }}$ & $12.1^{\mathrm{a}}$ & $19.0^{\mathrm{a}}$ & 4.27 & 12.9 \\
\hline $600 / 20$ & 92.3 & $90.1^{\mathrm{a}}$ & $84.9^{\mathrm{a}}$ & $0.080^{\mathrm{c}}$ & -0.300 & $-0.795^{\mathrm{a}}$ & $8.32^{b c}$ & $12.6^{\mathrm{a}}$ & $17.8^{\mathrm{a}}$ & 4.68 & 12.1 \\
\hline SE & 2.02 & 3.30 & 3.77 & 0.235 & 0.479 & 1.55 & 0.865 & 1.66 & 3.77 & 0.66 & 2.55 \\
\hline
\end{tabular}

${ }^{\mathrm{a}-\mathrm{c}}$ Means within a column with the same letter are not significantly different $(P<0.05)$.

${ }^{1} \mathrm{~L}^{*}=$ lightness $\left(0\right.$ to 100 , black to white), $\mathrm{a}^{*}=$ redness (negative, green; positive, red), and $\mathrm{b}^{*}=$ yellowness (positive, yellow; negative, blue).

at 200 or $400 \mathrm{MPa}$ were clustered around the control in the lower negative quadrant, with the QF processed at $600 \mathrm{MPa}$ above it. This confirms that processing at $20^{\circ} \mathrm{C}$ and at lower pressures resulted in QF similar to the control. The QF warmed to $40^{\circ} \mathrm{C}$ before HPP (enclosed in circles) were spread out on the positive PC1 axis and far removed from the $40^{\circ} \mathrm{C}$ control (enclosed in squares in lower left quadrant). As HPP pressure increased, the PC1 values went from negative to positive. Vectors for the textural and rheological properties had positive $\mathrm{PC} 1$ values, ranging on the $\mathrm{PC} 2$ axis from negative values for the texture properties (springiness, cohesion, and chewiness) to positive values for the torsion analysis properties (fracture stress and rigidity).

Microstructure. Slight differences were noted in the microstructure of the QF following HPP treatment (Figure 6). Cheese that had not undergone HPP exhibited cavities corresponding to fat globules (black arrow) with diameters up to $4 \mu \mathrm{m}$, irregular crevices to hold moisture (white arrow), and casein micelles (double arrow) that were still identifiable in the protein strands that formed the cheese matrix (Figure 6a). After processing under the most severe conditions used in this study (600 MPa for $20 \mathrm{~min}$ ), the matrix became slightly tighter and micelles lost their individual appearance as they fused into thicker strands (Figure 6b). The microstructural changes were indicative of compression of the protein matrix, which accounted for the trends in the rheological results. We did not observe the severe loss of protein structure and organization in the microstructure of QF reported by Hnosko et al. (2012). In that study, HPP treatments ranging from 400 to 600 $\mathrm{MPa}$ for up to 25 min resulted in QF that had a fused protein matrix with few openings in the mass, a sticky texture, and poor crumbling properties. Although factors such as the presence of starter cultures, lower $\mathrm{pH}$ in the cheese matrix, and pressing before packaging will influence the physical makeup of the cheese matrix, it is unclear why the HPP in similar pressures and times more severely altered in the functionality and microstructure of the QF in the Hnosko et al. (2012) study.

High-pressure processing is known to alter proteins and enzymes, changes that may or may not be reversible (Knorr et al., 2006). Although covalent bonds are typically not affected by HPP, other interactions, especially those involving water, will alter stability and activity of enzymes and the conformation and flexibility of proteins. High-pressure processing will also compress the secondary and tertiary structural domains of proteins, although $\alpha$-helix and $\beta$-sheets appear to be incompressible. In milk, the whey proteins are particularly susceptible to heat and pressure denaturation, and HPP of cheesemilk will result in higher cheese yields because of the retention of whey proteins in the cheese matrix 

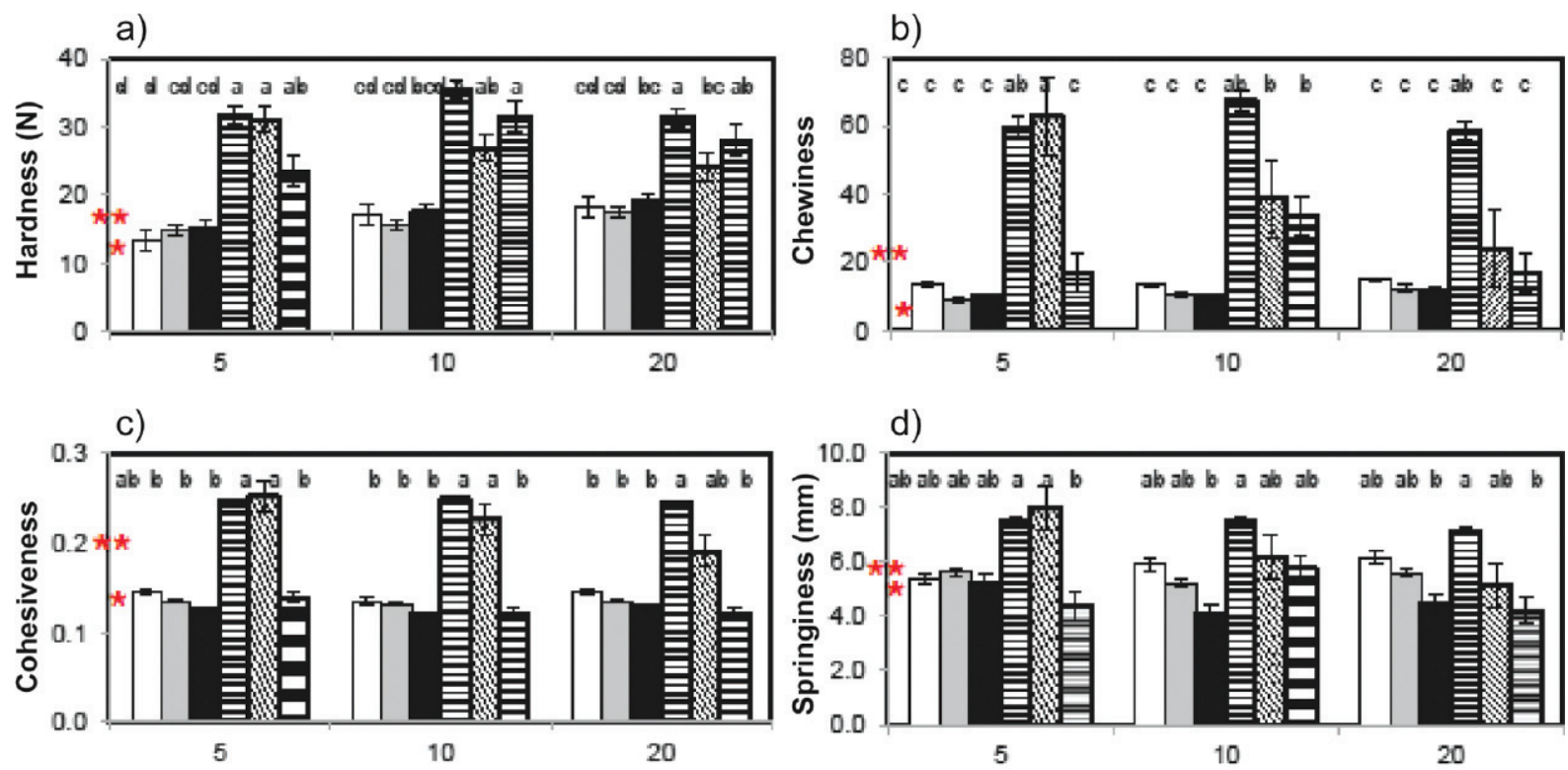

e)

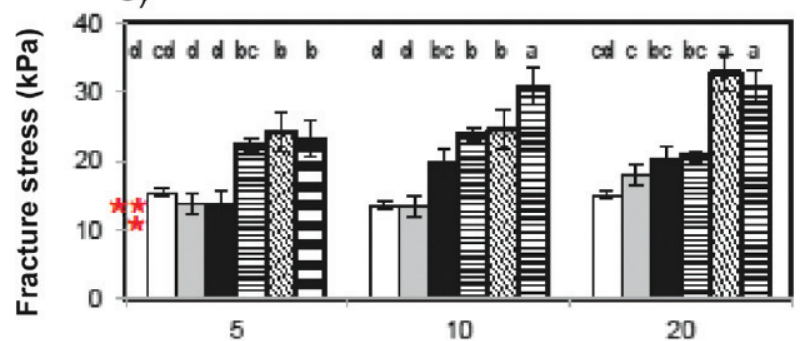

f)

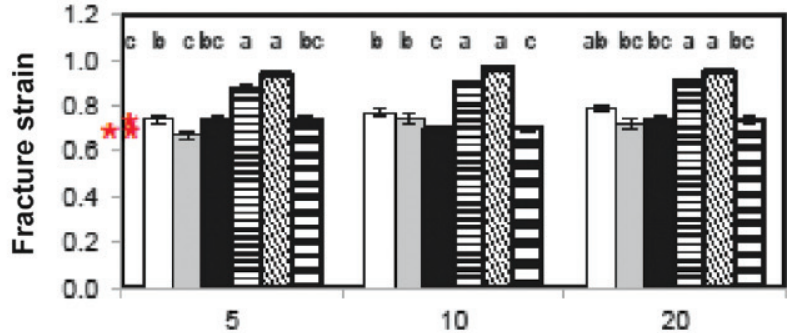

g)

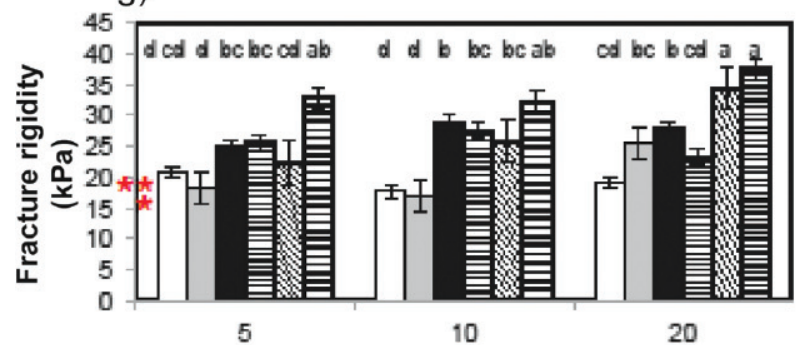

h)
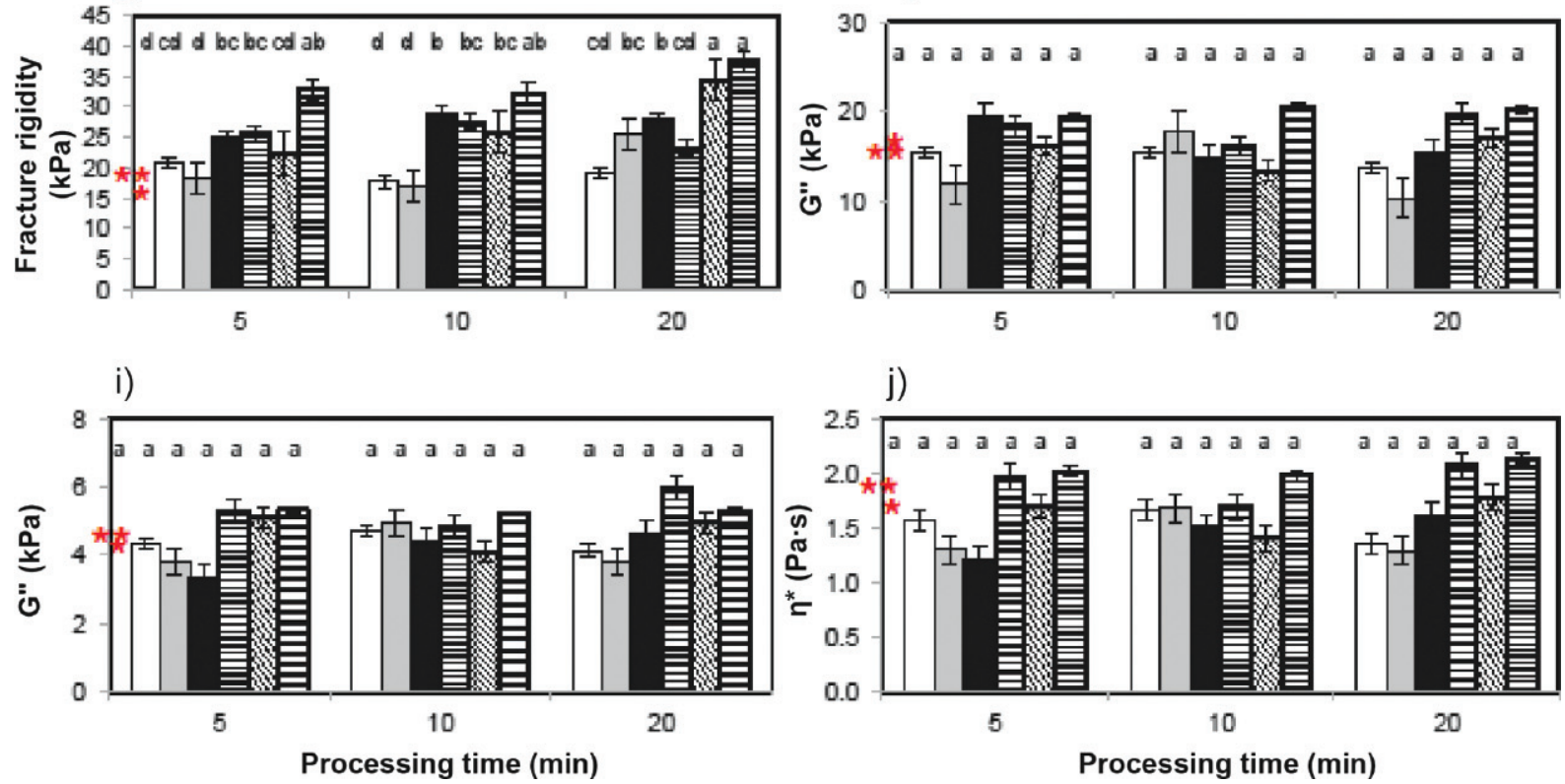

Figure 4. Textural properties [(a) hardness, (b) chewiness, (c) cohesiveness, and (d) springiness] and rheological properties [(e) fracture stress, (f) fracture strain, (g) fracture rigidity, (h) elastic modulus $\left(\mathrm{G}^{\prime}\right)$, (i) viscous modulus $\left(\mathrm{G}^{\prime \prime}\right)$, and (j) complex viscosity ( $\left.\eta^{*}\right)$ ] of Queso Fresco (QF) processed at high pressures for 5, 10, or 20 min. Treatments included QF warmed to core temperature of $20^{\circ} \mathrm{C}$ and high-pressure processing (HPP) at 200 (white fill), 400 (gray fill), or 600 (black fill) MPa or warmed to $40^{\circ} \mathrm{C}$ and HPP at 200 (horizontal line fill), 400 (diagonal line fill), or 600 (thin horizontal line fill) $\mathrm{MPa} ; 20^{\circ} \mathrm{C}$ control $(*)$, and $40^{\circ} \mathrm{C}$ control $(* *)$. Error bars indicate standard errors. Color version available in the online PDF. 


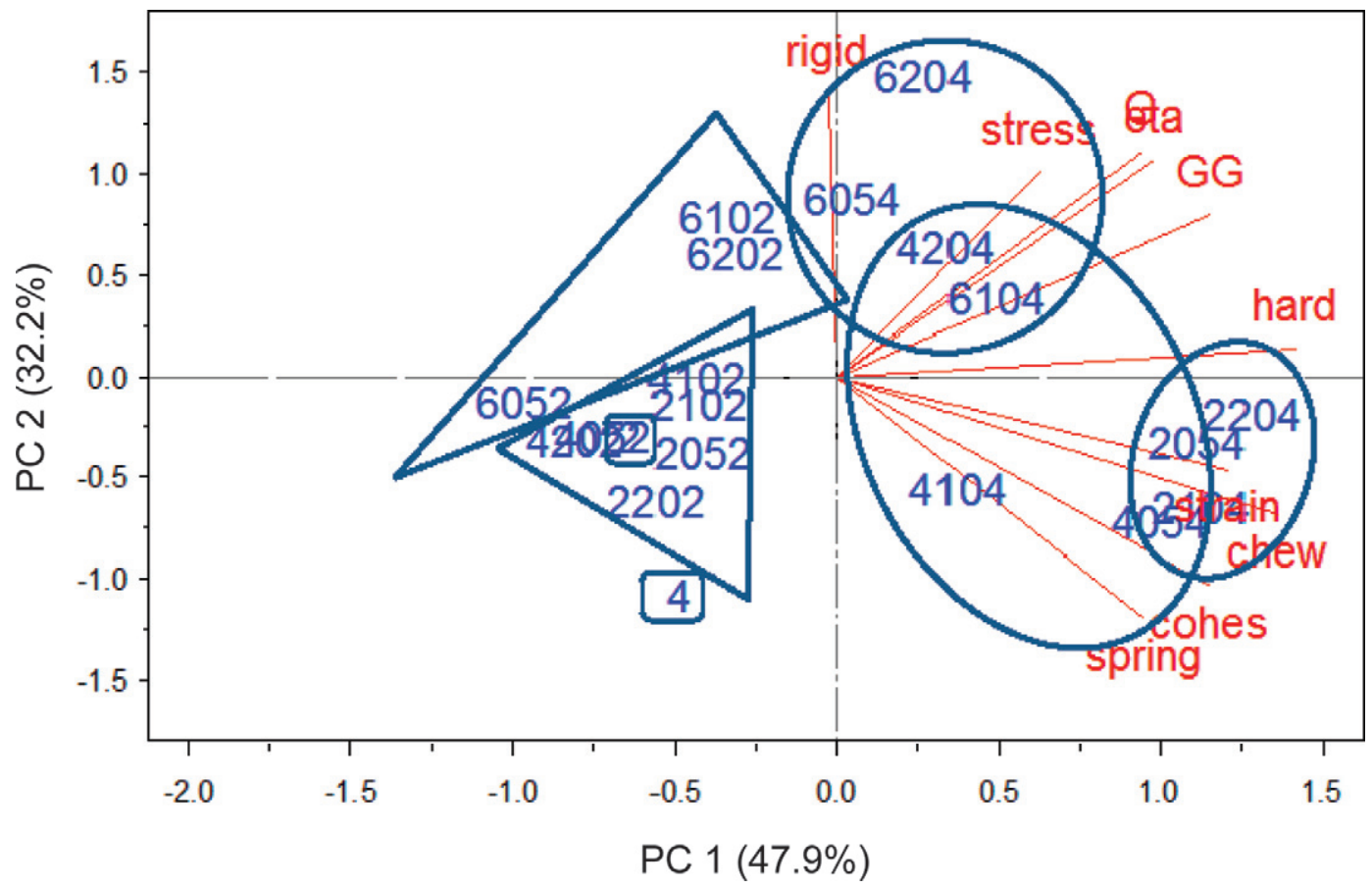

Figure 5. Principal component (PC) analysis of the textural and rheological variability among the 21 different high-pressure processing (HPP) treatments. The single-digit codes inside rectangles denote controls warmed to $20^{\circ} \mathrm{C}(2)$ or $40^{\circ} \mathrm{C}(4)$. The 4 -digit codes indicate the $\mathrm{HPP}$ treatment, where the first digit indicates pressure $(2=200 \mathrm{MPa}, 4=400 \mathrm{MPa}, 6=600 \mathrm{MPa})$, the next 2 digits indicate exposure time (05, 10 , or $20 \mathrm{~min}$ ), and the last digit indicates the internal temperature of the cheese before treatment $\left(2=20^{\circ} \mathrm{C}\right.$, enclosed in triangles; $4=40^{\circ} \mathrm{C}$, enclosed in circles). Rigid $=$ rigidity, stress $=$ fracture stress, eta $=$ complex viscosity, hard $=$ hardness, chew $=$ chewiness, cohes $=$ cohesiveness, spring $=$ springiness, strain $=$ fracture strain. Color version available in the online PDF.
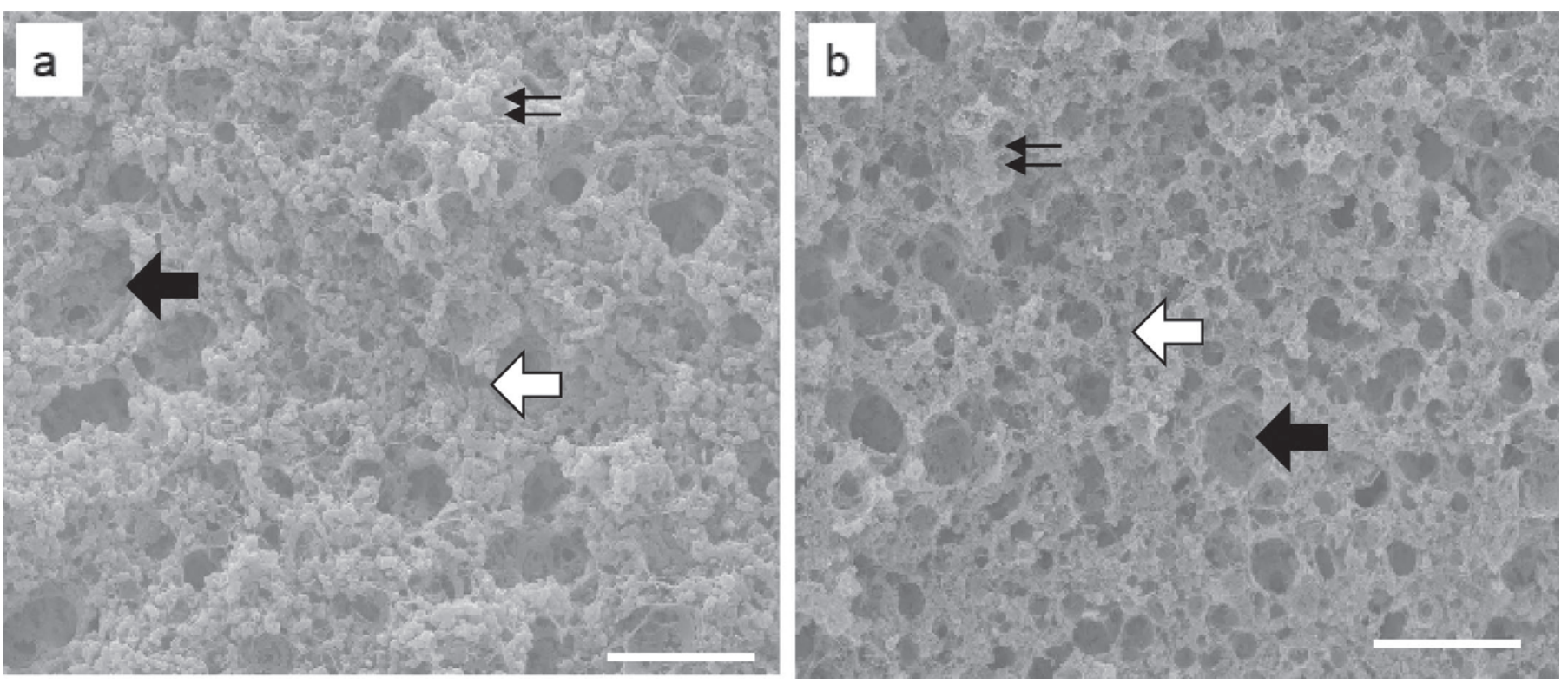

Figure 6. Scanning electron micrographs of Queso Fresco (QF) warmed to core temperature of $20^{\circ} \mathrm{C}$ and (a) not exposed to high-pressure processing (control) or (b) processed at $600 \mathrm{MPa}$ for $20 \mathrm{~min}$. Cheese matrix consists of strands of casein micelles (double arrow) that entrap fat droplets (black arrows point to empty cavity that held lipid droplet) with irregular crevices (white arrow) among the protein strands that hold moisture. The scale bar represents $5.0 \mu \mathrm{m}$. 
(Sandra et al., 2004). In finished cheese, utilization of HPP compresses the protein matrix of the cheese, altering functional and rheological properties (Trujillo et al., 2002; Okpala et al., 2010; Hnosko et al., 2012; Evert-Arriagada et al., 2012). Although HPP has the appeal of extending shelf life of a high-moisture fresh cheese through inactivation of enzymes and spoilage microorganisms, the effect of the high pressure on the structural characteristics of the cheese must be carefully considered.

In phase 1, multiple HPP pressures, exposure times, and temperatures were evaluated to determine the effect of HPP on the quality traits of QF. High-pressure processing is more effective at eliminating bacteria in high-moisture, starter-free cheeses when conducted at higher temperatures (Capellas et al., 2000, 2001), which theoretically could reduce the pressure and exposure times needed for HPP treatments. Unfortunately, excessive wheying-off occurred when QF was warmed to $40^{\circ} \mathrm{C}$ before $\mathrm{HPP}$. The rheological properties of $\mathrm{QF}$ processed at $20^{\circ} \mathrm{C}$ were more stable and closer to the controls compared with $\mathrm{QF}$ warmed to $40^{\circ} \mathrm{C}$. Therefore, room temperature $\left(20^{\circ} \mathrm{C}\right)$ was selected for the processing temperature for phase 2. When HPP was conducted at $20^{\circ} \mathrm{C}$ for $5 \mathrm{~min}$, most of the texture profile analysis and torsion properties were similar. With 10-min exposures, QF treated at $600 \mathrm{MPa}$ were less springy and more rigid. In a concurrent study, the $5 \mathrm{~min} / 600 \mathrm{MPa}$ treatment was effective in eliminating Listeria monocytogenes, and we subsequently identified the $600 \mathrm{MPa}$ pressure as the pressure to pursue for commercial use. Therefore, the $600 \mathrm{MPa}$ was selected for phase 2 but with exposure times of 3 and $10 \mathrm{~min}$. With the processing conditions selected, phase 2 examined the effects of $\mathrm{HPP}$ on the quality traits of QF stored at 4 and $10^{\circ} \mathrm{C}$ for up to 12 wk to determine if HPP maintained or shortened the quality shelf life of QF.

\section{Phase 2}

Composition and $\boldsymbol{p H}$. In phase 2, fresh control QF contained an average of $56.1 \pm 0.4 \%$ moisture, $15.4 \pm 0.5 \%$ protein, $22.3 \pm 0.3 \%$ fat, $2.9 \pm 0.1 \%$ lactose, $2.0 \pm 0.3 \%$ salt, and $3.3 \pm 0.1 \%$ ash, and had $\mathrm{pH} 6.31 \pm 0.03$. In phase 2 , the control cheeses had significantly higher moisture levels than QF processed at $600 \mathrm{MPa}$ but no differences were noted between the $\mathrm{QF}$ processed for 3 or $10 \mathrm{~min}$ (Table 4). The control cheeses continued to have higher moisture levels $(P<$ 0.05) than the QF processed for 10 min throughout the study. Storage conditions also influenced reduction in moisture. Although the control and cheese processed for $10 \mathrm{~min}$ had significantly less moisture after $12 \mathrm{wk}$ of storage, the $\mathrm{QF}$ stored at $10^{\circ} \mathrm{C}$ tended to have the lowest values. Unlike phase 1 , the variation noted in the protein measurements resulted in no significant differences among the means. Although the moisture content was decreasing, slight shifts $(P>0.05)$ were noted in protein, fat, lactose, and ash but not enough to be labeled as significant. By wk 12, the $3 \mathrm{QF}$ stored at $10^{\circ} \mathrm{C}$ were below $\mathrm{pH} 6.1$ and had significantly lower lactose concentrations, which were clear indications of spoilage.

Queso Fresco controls lost 2\% free whey over the course of the study, which was reflected in the decrease in moisture content. These results agree with findings from previous studies from our laboratory (Tunick et al., 2012; Van Hekken et al., 2012). The HPP of QF resulted in additional loss of free whey of up to $2.6 \%$. Other major components were stable among treatments and over the study $(P>0.05)$ : protein, 15.0 to $17.5 \%$, fat, 22.3 to $23.9 \%$; lactose, 1.9 to $3.0 \%$; and ash, 3.2 to $3.6 \%$. The $\mathrm{pH}$ of the $\mathrm{QF}, \mathrm{pH} 6.2$ to 6.5 , was stable within treatments over the $12 \mathrm{wk}$ of storage. By wk 12 , the $\mathrm{QF}$ stored at $10^{\circ} \mathrm{C}$ exhibited evidence of spoilage,

Table 4. Means $( \pm \mathrm{SD})$ of moisture and protein contents of Queso Fresco following high-pressure processing treatment at $600 \mathrm{MPa}$ for 0,3 , or $10 \mathrm{~min}$ and then stored at 4 or $10^{\circ} \mathrm{C}$ for up to $12 \mathrm{wk}$

\begin{tabular}{|c|c|c|c|c|c|c|c|c|}
\hline Item & \multicolumn{4}{|c|}{$4^{\circ} \mathrm{C}$} & \multicolumn{4}{|c|}{$10^{\circ} \mathrm{C}$} \\
\hline \multicolumn{9}{|c|}{ Moisture (\%) } \\
\hline $3 \mathrm{~min}$ & $54.5 \pm 1.1^{\mathrm{bc}}$ & $53.7 \pm 0.8^{\mathrm{bcd}}$ & $53.8 \pm 0.5^{\mathrm{bcd}}$ & $52.9 \pm 1.2^{\text {bcde }}$ & $53.6 \pm 0.5^{\mathrm{bcd}}$ & $52.7 \pm 0.1^{\text {cde }}$ & $51.9 \pm 0.1^{\mathrm{de}}$ & $52.1 \pm 0.6^{\mathrm{e}}$ \\
\hline $10 \mathrm{~min}$ & $53.9 \pm 0.7^{\mathrm{bc}}$ & $52.8 \pm 0.3^{\mathrm{cd}}$ & $52.6 \pm 0.2^{\mathrm{de}}$ & $52.0 \pm 0.8^{\mathrm{de}}$ & $53.6 \pm 0.4^{\mathrm{bcd}}$ & $52.3 \pm 0.2^{\mathrm{de}}$ & $51.8 \pm 0.7^{\mathrm{e}}$ & $51.5 \pm 0.6^{\mathrm{e}}$ \\
\hline \multicolumn{9}{|c|}{ Protein (\%) } \\
\hline $10 \mathrm{~min}$ & $17.5 \pm 1.3^{\mathrm{abc}}$ & $18.5 \pm 0.9^{\mathrm{ab}}$ & $18.6 \pm 0.7^{\mathrm{ab}}$ & $19.3 \pm 0.8^{\mathrm{a}}$ & $17.9 \pm 1.0^{\mathrm{abc}}$ & $19.0 \pm 0.6^{\mathrm{ab}}$ & $19.4 \pm 1.8^{\mathrm{a}}$ & $19.9 \pm 0.9^{\mathrm{a}}$ \\
\hline
\end{tabular}

\footnotetext{
${ }^{\mathrm{a}-\mathrm{e}}$ Means within either moisture content or protein content having the same letter are not significantly different $(P<0.05)$.
} 


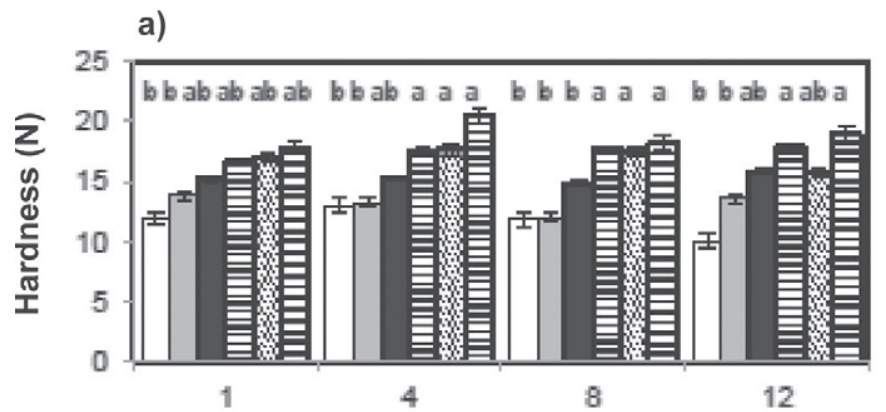

c)

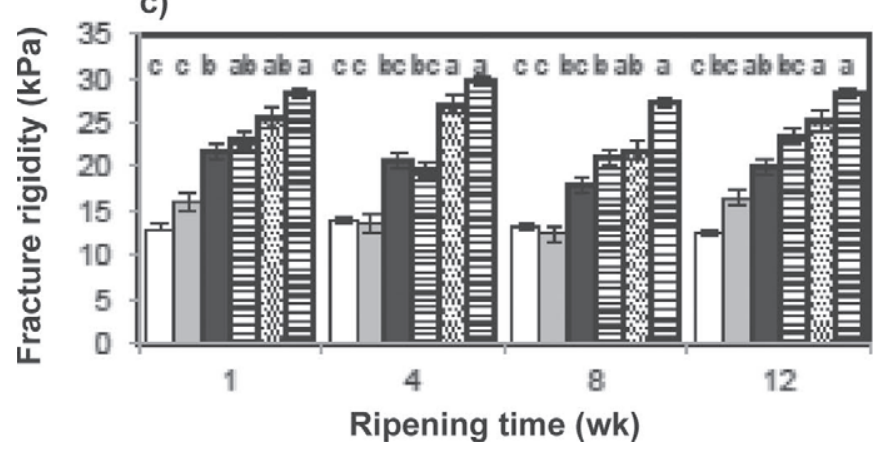

b)

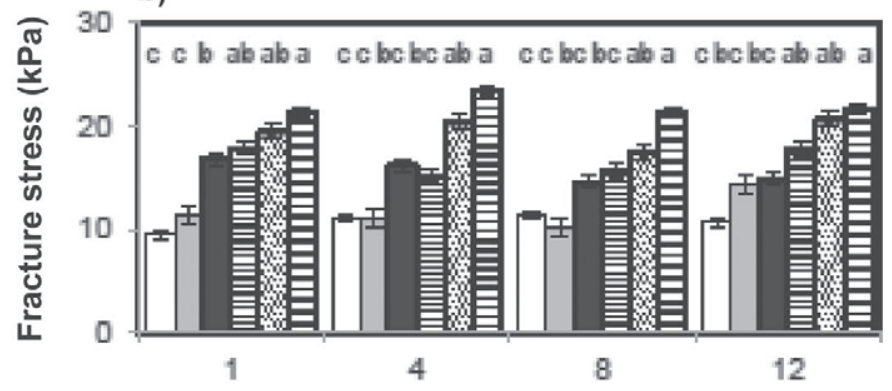

d)

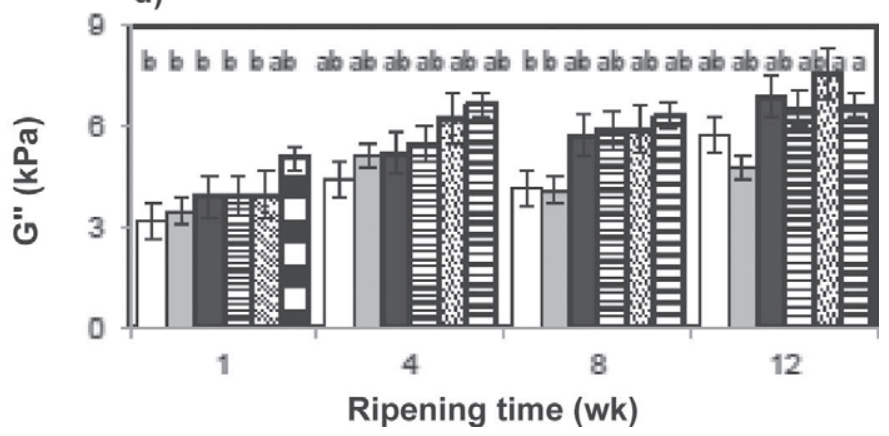

Figure 7. Textural properties [(a) hardness] and rheological properties [(b) fracture stress, (c) fracture rigidity, and (d) viscous modulus] of Queso Fresco $(\mathrm{QF})$ processed at $600 \mathrm{MPa}$ and stored for up to 12 wk. Treatments include control stored at $4^{\circ} \mathrm{C}$ (white fill) or $10^{\circ} \mathrm{C}$ (gray fill), QF processed for $3 \mathrm{~min}$ and stored at $4^{\circ} \mathrm{C}$ (black fill) or $40^{\circ} \mathrm{C}$ (horizontal line fill), and QF processed for 10 min and stored at $4^{\circ} \mathrm{C}($ diagonal line fill) or $10^{\circ} \mathrm{C}$ (thin horizontal line fill). Error bars indicate standard errors.

occasional surface bacteria growth, the lowest concentrations of lactose, and $\mathrm{pH}<6.0$.

Functional Properties. The QF in phase 2 had similar $\mathrm{L}, \mathrm{a}^{*}$, and $\mathrm{b}^{*}$ values and responded to heating at $130^{\circ} \mathrm{C}$ for $30 \mathrm{~min}$ and $232^{\circ} \mathrm{C}$ for $5 \mathrm{~min}$ as reported in phase 1 .

Texture and Rheological Properties. The rheological properties were stable $(P>0.05)$ over the 12 wk of the study within the treatment and storage temperature groups. The $\mathrm{QF}$ processed at $600 \mathrm{MPa}$ were firmer than the controls and increased in firmness as the length of exposure increased and as the storage temperature increased $(P<0.05$; Figure 7$)$. Hardness for $\mathrm{QF}$ processed at $600 \mathrm{MPa}$ ranged from 10.0 to 20.5 $\mathrm{N}$ (controls in 10.0 to $13.9 \mathrm{~N}$ range), fracture stress ranged from 9.5 to $23.3 \mathrm{MPa}$ (controls in the 9.5 to 14.3 MPa range), and fracture rigidity ranged from 12.3 to $29.8 \mathrm{MPa}$ (controls in the 12.3 to $17.0 \mathrm{MPa}$ range). Cheeses stored at $10^{\circ} \mathrm{C}$ tended to be firmer than their $4^{\circ} \mathrm{C}$ counterparts but not always at a significant level $(P>0.05)$. This effect is probably due to the greater loss of whey from the cheese block at the higher storage temperature, in agreement with the finding of Tunick et al. (2012), who reported similar loss of whey during storage at $10^{\circ} \mathrm{C}$. Only the viscous modulus was altered as the cheese aged; all other properties were very stable over the 12 wk of the study. The 2 controls had the highest values for springiness at wk 1 , but this difference was lost by wk 4. Queso Fresco is known for its fragile texture and is expected to crumble easily, accounting for the low values for rheological properties relative to other cheeses.

The control QF lost free whey during storage and the use of postpackaging processing at $600 \mathrm{MPa}$ resulted in additional loss of free whey. American consumers view the presence of whey in packaging as a defect. Although the commercial QF cheesemaking protocol used in this study specifically did not include a pressing step, the extra wheying-off of the cheese during HPP might be significantly reduced by pressing the cheese before packaging.

The increase in cheese firmness and higher stress required for fracture of the cheese matrix following HPP suggest that the crumbling characteristic of QF (Hwang and Gunasekaran, 2001; Sandra et al., 2004) would be impaired. Hnosko et al. (2012) also found that crumbliness was reduced by HPP. In contrast, Sandra et al. (2004) reported that HPP (400 MPa for $20 \mathrm{~min}$ ) of pressed QF had minimal effect on the texture of the cheese.

Sensory Analysis. The matrix of QF is so fragile that it is expected to crumble and break apart easily; the proper mouthfeel is a critical quality trait for consumers. All of the 30 untrained panelists, 15 males and 
15 females, consumed cheese regularly, with half being familiar with Hispanic-style cheeses. In difference tests, panelists distinguished between control and QF that had the HPP treatment ( 3 min, $P<0.05$ or $10 \mathrm{~min}, P$ $<0.01)$ but could not tell the difference between the 3 or 10 min HPP QF samples $(P>0.05)$. The overall flavor hedonic score for the control QF was $2.8 \pm 1.4$ ("liked very much"), whereas the HPP QF received scores of $3.4 \pm 1.6$ for HPP for $3 \mathrm{~min}$ and $3.4 \pm 1.4$ for HPP at 10 min ("moderately liked"). The overall texture hedonic scores for the QF were similar, 3.2, 3.6, and 3.5 for control and HPP at 3 and 10 min, respectively. Panelists familiar with QF were more accepting of the texture than those not familiar with QF; flavor scores were similar. Sandra et al. (2004) used a descriptive texture panel to characterize the attributes of $\mathrm{QF}$ processed at $400 \mathrm{MPa}$ for $20 \mathrm{~min}$ and reported that it was slightly less crumbly than the nonprocessed control QF and, after $8 \mathrm{~d}$ of storage at $4^{\circ} \mathrm{C}$, the HPP QF was more yellow and had higher stickiness and sticky residue scores. Daryaei et al. (2006) reported that untrained panelists could not tell the difference between untreated and treated (300 and $600 \mathrm{MPa}$ for $5 \mathrm{~min}$ ) fresh lactic acid curd cheese containing herbs. EvertArriagada et al. (2012) reported that fresh rennet-set, starter-free cheeses processed at 300 or $400 \mathrm{MPa}$ for 5 min were firmer, less watery, and more yellow than non-HPP cheese, but found no significant differences in flavor or aroma.

\section{CONCLUSIONS}

The appeal of HPP to improve the safety and shelf life of high-moisture cheese is limited by the changes in quality traits that result from exposure to pressures high enough to eliminate pathogens or inactivate degradation enzymes. Changes noted in this study, such as excessive wheying-off and changes in textural and rheological properties, will influence consumer acceptance of this product, and cheese producers must be aware of how the higher pressures will alter the quality of their cheese. More research is required to find the optimum conditions for using HPP in producing a high-quality Hispanic-style cheese with a longer shelf life that meets the expectations of the American consumer.

\section{ACKNOWLEDGMENTS}

The authors thank the following Agricultural Research Service researchers for their contribution to this study: Raymond Kwoczak, Joseph Sites, Latasha Leggett, James Shieh, Brien Sullivan, and Danielle Tilman (all of Agricultural Research Service, Wyndmoor, PA). Research was partially funded by Dairy Manage- ment Inc., administered by the Dairy Research Institute (Rosemont, IL).

\section{REFERENCES}

AOAC International. 2000. Official Methods of Analysis. 17th ed. AOAC International, Gaithersburg, MD.

Capellas, M., M. Mor-Mur, R. Gervilla, J. Yuste, and B. Guamis. 2000. Effect of high pressure combined with milk heat or nisin on inoculated bacteria and mesophiles of goat's milk fresh cheese. Food Microbiol. 17:633-641.

Capellas, M., M. Mor-Mur, E. Sendra, and B. Guamis. 2001. Effect of high-pressure processing on physic-chemical characteristic of fresh goats' milk cheese (Mató). Int. Dairy J. 11:165-173.

Chawla, R., G. R. Patil, and A. K. Singh. 2011. High hydrostatic pressure technology in dairy processing: A review. J. Food Sci. Technol. 48:260-268.

Daryaei, H., M. J. Coventry, C. Versteeg, and F. Sherkat. 2006. Effects of high-pressure treatments on shelf life and quality of fresh lactic curd cheese. Aust. J. Dairy Technol. 61:186-188.

Evert-Arriagada, K., M. M. Hernandez-Herrero, B. Juan, B. Guamis, and A. J. Trujillo. 2012. Effect of high pressure on fresh cheese shelf-life. J. Food Eng. 110:248-253.

Evrendilek, G. A., N. Koca, J. W. Harper, and V. M. Balasubramaniam. 2008. High-pressure processing of Turkish white cheese for microbial inactivation. J. Food Prot. 71:102-108.

Guo, L., D. L. Van Hekken, P. M. Tomasula, J. Shieh, and M. H. Tunick. 2011. Effect of salt on the chemical, functional, and rheological properties of Queso Fresco during storage. Int. Dairy J. 21:352-357.

Hnosko, J., M. F. San-Martin Gonzalez, and S. Clark. 2012. High pressure processing inactivated Listeria innocua yet compromises Queso Fresco crumbling properties. J. Dairy Sci. 95:4851-4862.

Hunter, R. S. 1975. The Measurement of Appearance. John Wiley and Sons Inc., New York, NY.

Hwang, C. H., and S. Gunasekaran. 2001. Measuring crumbliness of some commercial queso fresco type Latin American cheeses. Milchwissenschaft 56:446-450.

Johnston, D. E., and P. C. Darcy. 2000. The effect of high pressure treatment on immature Mozzarella cheese. Milchwissenschaft 55:617-620.

Knorr, D., V. Heinz, and R. Buckow. 2006. High pressure application for food biopolymers. Biochim. Biophys. Acta 1764:619-631.

Kosikowski, F. V., and V. V. Mistry. 1997. Chapter 21: Analysis. Pages 212-214 in Cheese and Fermented Milk Foods. Vol. 2. Procedures and Analysis. 3rd ed. F.V. Kosikowski LLC, Westport, CT.

Leggett, L. N., P. M. Tomasula, D. L. Van Hekken, A. C. S. PortoFett, B. Shoyer, J. A. Renye, J. B. Luchansky, and N. Farkye. 2012. Effect of storage at 4 and $10^{\circ} \mathrm{C}$ on the growth of Listeria monocytogenes in and on Queso Fresco. J. Food Saf. 32:236-245.

MacDonald, P. D. M., R. E. Whitwam, J. D. Boggs, J. N. MacCormack, K. L. Anderson, J. W. Reardon, J. R. Saah, L. M. Graves, S. B. Hunter, and J. Sobel. 2005. Outbreak of listeriosis among Mexican immigrants as a result of consumption of illicitly produced Mexican-style cheese. Clin. Infect. Dis. 40:677-682.

Meilgaard, M., G. V. Civille, and B. T. Carr. 1999. Overall Difference Tests. Pages 59-98 in Sensory Evaluation Techniques. 3rd ed. CRC Press, New York, NY.

Norton, T., and D.-W. Sun. 2008. Recent advances in the use of high pressure as an effective processing technique in the food industry. Food Bioprocess. Technol. 1:2-34.

Okpala, C. O. R., J. R. Piggott, and C. J. Schaschke. 2010. Influence of high-pressure processing (HPP) on physico-chemical properties of fresh cheese. Innov. Food Sci. Emerg. Technol. 11:61-67.

Olson, D. W., D. L. Van Hekken, M. H. Tunick, K. A. Soryal, and S. S. Zeng. 2007. Effects of aging on functional properties of caprine milk made into Cheddar- and Colby-like cheeses. Small Rumin. Res. 70:218-227.

Rasanayagam, V., V. M. Balasubramaniam, E. Ting, C. E. Sizer, C. Bush, and C. Anderson. 2003. Compression heating of selected 
fatty food materials during high-pressure processing. J. Food Sci. 68:254-259.

Sandra, S., M. A. Stanford, and L. Meunier Goddik. 2004. The use of high-pressure processing in the production of Queso Fresco cheese. J. Food Sci. 69:FEP153-FEP158.

Thomas, M. A. 1969. Browning reaction in Cheddar cheese. Aust. J. Dairy Technol. 24:185-189.

Trujillo, A.J., M. Capellas, J. Saldo, R. Gervilla, and B. Guamis. 2002. Applications of high-hydrostatic pressure on milk and dairy products: A review. Innov. Food Sci. Emerg. Technol. 3:295-307.

Tunick, M. H., D. L. Van Hekken, and P. H. Cooke. 2008. Rheology and microstructure of Queso Blanco as affected by pressing procedure and storage conditions. Milchwissenschaft 63:157-160.
Tunick, M. H., D. L. Van Hekken, S. K. Iandola, and P. M. Tomasula. 2012. Characterization of Queso Fresco during storage at 4 and $10^{\circ}$ C. J. Food Res. 1:308-319.

USDA-NASS (US Department of Agriculture National Agricultural Statistics Service). 2013. Dairy Products November 2012. Highlights. Accessed Jan. 3, 2013. http://usda.mannlib.cornell.edu/ usda/current/DairProdu/DairProd-01-03-2013.pdf.

Van Hekken, D. L., M. H. Tunick, L. N. Leggett, and P. M. Tomasula. 2012. Impact of curd milling on the chemical, functional, and rheological properties of starter-free Queso Fresco. J. Dairy Sci. 95:5527-5535.

Van Hekken, D. L., and N. Y. Farkye. 2003. Hispanic cheeses: The quest for queso. Food Technol. 57:32-38. 